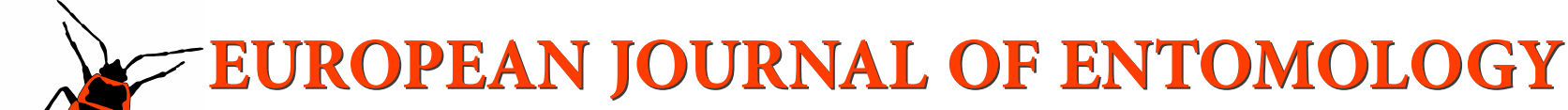 \\ ISSN (online): 1802-8829 \\ http://www.eje.cz \\ Eur. J. Entomol. 116: 486-491, 2019 \\ doi: 10.14411/eje.2019.050 \\ ORIGINAL ARTICLE
}

\section{Methods for retaining well-preserved DNA with dried specimens of insects}

\author{
NAOYUKI NAKAHAMA' 1 , YuJ ISAGI ${ }^{2}$ and Motomı ITO ${ }^{3}$ \\ ${ }^{1}$ Institute of Natural and Environmental Sciences, University of Hyogo, 6 chome, Yayoigaoka, Sanda, Hyogo 669-1546, Japan; \\ e-mail: naoyuki.halobates@gmail.com \\ ${ }^{2}$ Graduate School of Agriculture, Kyoto University, Kyoto 606-8502, Japan; e-mail: isagiy@kais.kyoto-u.ac.jp \\ ${ }^{3}$ Graduate School of Arts and Sciences, University of Tokyo, Tokyo 153-8902 Japan; e-mail: cmito@mail.ecc.u-tokyo.ac.jp
}

\begin{abstract}
Key words. Orthoptera, Gryllidae, Acheta domestica, DNA fragmentation, dried specimens of insects, genetic analysis,
\end{abstract} propylene glycol

\begin{abstract}
Dried specimens of insects are increasingly seen as genetic resources. However, genetic analysis of dried specimens of insects is hampered by the deterioration of the DNA. In this study, we developed methods for preparing dried specimens of insects with well-preserved DNA, mainly for PCR-based genetic analysis. First, we compared the effects of either exposure to ethyl acetate vapour for from $10 \mathrm{~min}$ to $6 \mathrm{~h}$ or by freezing on the fragmentation of DNA in order to determine optimal length of time needed for killing insects using the above methods. Second, we compared the fragmentation of DNA after preservation by drying or immersion of legs in $99.5 \%$ ethanol or $99 \%$ propylene glycol in $0.2-\mathrm{ml}$ tubes. We assessed degrees of fragmentation of DNA by determining polymerase chain reaction (PCR) success rates with primers for 313-, 710- and 1555-bp fragments using DNA that was collected immediately, and at one, six and 12 months after preparing the specimens. Differing times taken to kill insects did not affect the fragmentation of DNA. In dried specimens, DNA was seriously fragmented after one month, whereas that in legs prepared by immersion in $99.5 \%$ ethanol or $99 \%$ propylene glycol contained long fragments of DNA (1555 bp ) after 12 months. Propylene glycol was more suitable for preservation than ethanol, because the latter evaporates. Thus, to preserve insect DNA we suggest inserting the pin on which an insect is impaled into the hinged lid of a $0.2-\mathrm{ml}$ tube containing $99 \%$ propylene glycol so that when the lid is closed the legs of the insect are preserved in the solution.
\end{abstract}

\section{INTRODUCTION}

Insect specimens contain valuable genetic information (Wandeler et al., 2007; Tin et al., 2014; Nakahama et al., 2018). Such information is being used in applied entomology, conservation genetics and taxonomy, and reveals the history of the DNA sequences (Tin et al., 2014; Hausmann et al., 2016; Haran et al., 2018; Nakahama et al., 2018). However, there were very few studies on genetic information obtained from dried specimens of insects before the 2000 s, because the rapid degradation of DNA in dried specimens of insects renders them unsuitable for genetic analyses (Wandeler et al., 2007; Nakahama \& Isagi, 2017). In recent years, there have been many genetic analyses of dried specimens of insects, which reflects advances in genetic analyses of specimens with degraded DNA using high throughput sequencing and PCR-based analysis (Tin et al., 2014; Suchan et al., 2016; Nakahama \& Isagi, 2017). Genetic analyses using dried specimens of insects nonetheless remain technically difficult and costly. Hence it is important to develop methods for improving the preservation of DNA in insect specimens.
To prevent degradation, DNA samples are generally preserved in 95-99.5\% ethanol or acetone, or in a freezer, or a combination of these (preserved in $95-99.5 \%$ ethanol or acetone and stored in a freezer at $-20^{\circ} \mathrm{C}$ to $-80^{\circ} \mathrm{C}$ ) because this prevents DNA degradation (Reiss et al., 1995; Quicke et al., 1999; Vink et al., 2005; Nasu et al., 2016). However, the maintenance and space costs associated with immersed or frozen specimens are greater than those associated with dried specimens. The preservation of frozen specimens requires large freezers, which are expensive and may have limited space for specimen preservation and immersed specimens must be regularly checked to ensure that the stock solution has not evaporated. In addition, morphological observations and dissections of $99 \%$ ethanol-immersed specimens are difficult due to dehydration (Naem et al., 2010). To overcome these problems, we tested whether DNA in the legs of dried specimens of insects can be preserved for a long time. To this end we suspended insects on a pin in $0.2-\mathrm{ml}$ tubes with only the legs immersed in the preservation solution. We also considered the methods used for killing insects, because apart from dragonflies 

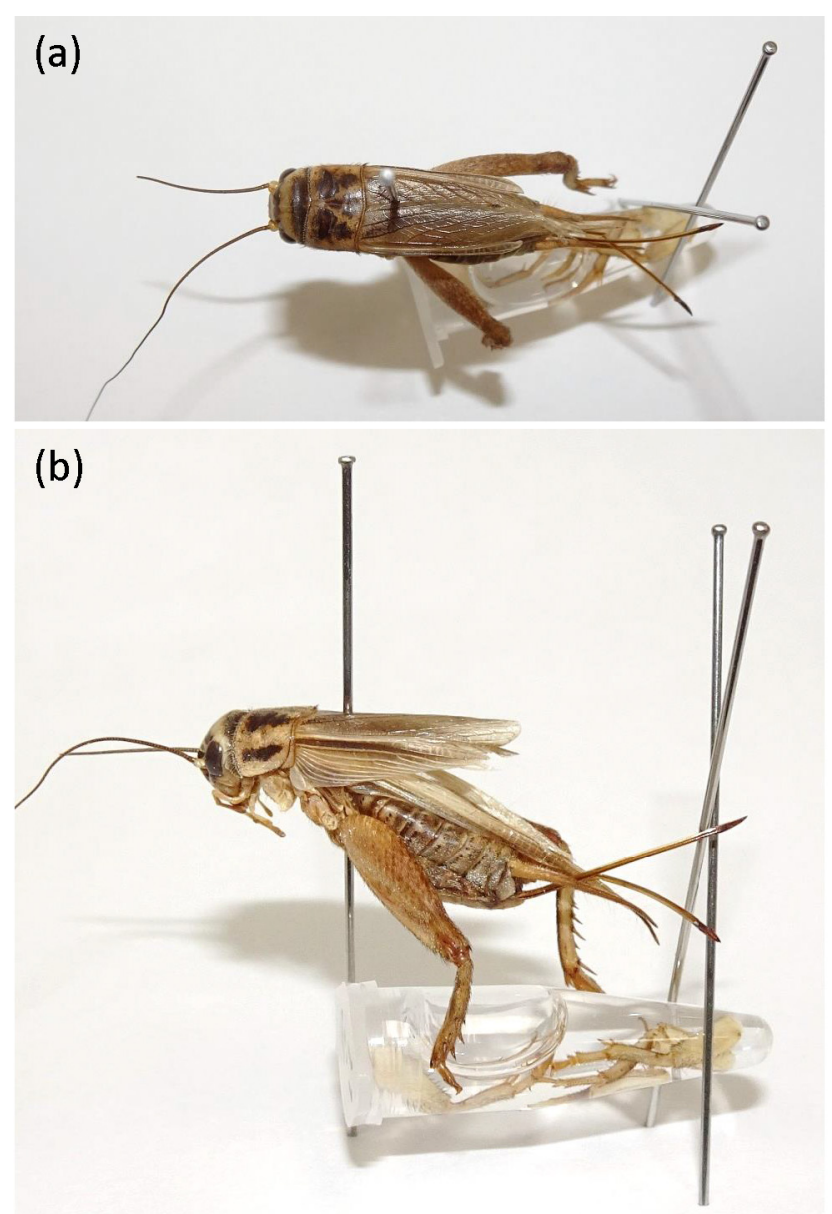

\section{$\underline{\text { Insect killing method }}$}

- Kill the insect in ethyl acetate vapor within one $\mathrm{h}$ or by freezing.

\section{Preservation method}

\section{- Cut the tissue (legs) from the insect body. \\ - Preserve the insect tissue in $99 \%$ propylene glycol in the $0.2 \mathrm{ml}$ tube. \\ - Insert the insect pin with dried specimen into the hinge of the $0.2 \mathrm{ml}$ tube. \\ - Preserve the specimen at room temperature. \\ - If the specimen is exposed to light, wrap the $0.2 \mathrm{ml}$ tube in aluminum foil. \\ - Fix the $0.2 \mathrm{ml}$ tube with insect pins.}

Fig. 1. Photograph of an insect specimen taken from (a) above and (b) the side, following preparation using the recommended method.

and butterflies, most insects are killed by exposing them to the vapour of ethyl acetate (Baba \& Hirashima, 2000), which results in a rapid degradation of the DNA (Reiss et al., 1995; Quicke et al., 1999). Thus, we compared the integrity of the DNA from insects that were killed either with ethyl acetate vapour or by freezing. Then, we compared preservatives in order to avoid ethanol and acetone which are unsuitable because they evaporate rapidly (evaporation rate of ethanol $=1.4$ and acetone $=7.7$ compared with $n$ butyl acetate $=1)$. We used propylene glycol because it does not evaporate (evaporation rate $=0.01$ compared with n-butyl acetate $=1$ ) and is known to preserve DNA (Vink et al., 2005). Herein, we assessed the degree of fragmentation of DNA by determining polymerase chain reaction (PCR) success rates. We also present methods for preparing and preserving dried specimens of insects with limited degradation of DNA for mainly PCR-based genetic analysis.

\section{MATERIAL AND METHODS}

\section{Preparation of insect specimens}

Female adult Acheta domestica (Orthoptera: Gryllidae) that were reared for feeding reptiles were purchased. Dry specimens were prepared using each of the following nine methods: (1) exposure to ethyl acetate vapour for ten minutes and preservation of whole bodies by drying, (2) exposure to ethyl acetate vapour for $1 \mathrm{~h}$ and preservation of whole bodies by drying, (3) exposure to ethyl acetate vapour for $6 \mathrm{~h}$ and preservation of whole bodies by drying, (4) freezing at $-30^{\circ} \mathrm{C}$ for $24 \mathrm{~h}$ and preservation by drying, (5) exposure to ethyl acetate vapour for $1 \mathrm{~h}$ followed by dehydration in $99.5 \%$ ethanol for $24 \mathrm{~h}$ and preservation of front and middle legs in $0.2-\mathrm{ml}$ tubes containing $99.5 \%$ ethanol, (6) exposure to ethyl acetate vapour for $1 \mathrm{~h}$ followed by dehydration in $99.5 \%$ ethanol for $24 \mathrm{~h}$ and preservation of front and middle legs in 0.2-ml tubes containing 99\% propylene glycol, (7) freezing at $-30^{\circ} \mathrm{C}$ for $24 \mathrm{~h}$ followed by dehydration in $99.5 \%$ ethanol for $24 \mathrm{~h}$ and preservation of front and middle legs in $0.2-\mathrm{ml}$ tubes containing $99.5 \%$ ethanol, (8) freezing at $-30^{\circ} \mathrm{C}$ for $24 \mathrm{~h}$ and dehydration in $99.5 \%$ ethanol for $24 \mathrm{~h}$ followed by preservation of front and middle legs in $0.2-\mathrm{ml}$ tubes containing $99 \%$ propylene glycol, and (9) freezing at $-30^{\circ} \mathrm{C}$ for $24 \mathrm{~h}$ and preservation of front and middle legs in $0.2-\mathrm{ml}$ tubes containing $99 \%$ propylene glycol (Table 1). Following the methods (5), (6), (7), (8) and (9), bodies of the insects were preserved as dried specimens without front and middle legs (Fig. 1). After methods (1), (2), (3) and (4), the effects of exposure to ethyl acetate vapour and freezing for different periods of time were compared by monitoring the fragmentation of DNA. Comparisons of the results of methods (1) and (9) indicated whether drying or immersion in ethanol or propylene glycol affected the fragmentation of DNA in preserved specimens. Comparisons of those of methods (8) and (9) revealed the effects of dehydration on fragmentation of DNA in tissues. Dilution of preservative solutions by the water from insect tissues reportedly promotes DNA fragmentation (Quicke et al., 1999; Stevens et al., 2011; Ferro et al., 2013). Each method was carried out using 12 samples. The weights of front and middle legs were $2.63 \pm 0.12 \mathrm{mg}$ and $2.56 \pm 0.09 \mathrm{mg}$, respectively (means \pm 
standard errors). After storage for zero (immediate group), one, six and 12 months, we measured DNA lengths using polymerase chain reactions (PCR). Prior to DNA extraction and PCR, we preserved legs in $99.5 \%$ ethanol at $-30^{\circ} \mathrm{C}$ so that DNA degradation would not proceed. In the immediate group, we only measured DNA lengths following methods (1), (2), (3) and (4), because the results obtained using the other methods were the same.

\section{Measurements of DNA fragmentation}

To evaluate DNA fragmentation, we determined PCR success rates with DNA from each specimen, as in previous studies (Kigawa et al., 2003; Särkinen et al., 2012; Nakahama \& Isagi, 2017). The PCR products of the primer pairs used were $313 \mathrm{bp}, 710 \mathrm{bp}$ and $1555 \mathrm{bp}$. The presence of DNA fragments that were longer than the PCR products indicated successful PCR amplification. From the 12 samples used in each method, we randomly selected eight for measurements of DNA fragment lengths. Genomic DNA was extracted from single front or middle legs using the phenol-chloroform method. The DNA extraction protocol is described in Appendix 1. DNA fragment lengths were determined using PCR with primer pairs for 313 (mlCOIintF: GGWACWGGWTGAACWGTWTAYCCYCC, HCO2198N-2175: TAAACTTCAGGGTGACCAAAAAATCA, Leray et al., 2013), 710 (LCO1490-J-1514: GGTCAACAAATCATAAAGATATTGG，HCO2198-N-2175: TAAACTTCAGGGTGACCAAAAAATCA, Folmer et al., 1994) and 1555 bp (COI TY-J1460: TACAATCTATCGCCTAAACTTCAGCC, T12-N-3014: TCCATTGCACTAATCTGCCATATTA, Simon et al., 1994). PCR reactions were performed in total volumes of $10 \mu \mathrm{L}$ containing $10 \mathrm{ng}$ of template DNA, $1 \times$ Ex Taq buffer, $200-\mu \mathrm{M}$ dNTPs, $0.2-\mu \mathrm{M}$ primers and $0.25 \mathrm{U}$ of Ex Taq (Takara). Amplification profiles for mlCOIintF and $\mathrm{HCO} 2198-\mathrm{N}-2175$ included initial denaturation at $95^{\circ} \mathrm{C}$ for 1 min, followed by 37 cycles of $94^{\circ} \mathrm{C}$ for $30 \mathrm{~s}, 44^{\circ} \mathrm{C}$ for $40 \mathrm{~s}$ and $72^{\circ} \mathrm{C}$ for $1 \mathrm{~min}$, and a final extension at $72^{\circ} \mathrm{C}$ for $10 \mathrm{~min}$. Amplification profiles for the other two primer pairs included initial denaturation at $95^{\circ} \mathrm{C}$ for $15 \mathrm{~min}$, followed by 35 cycles of $94^{\circ} \mathrm{C}$ for $30 \mathrm{~s}, 47^{\circ} \mathrm{C}$ for $1 \mathrm{~min}$ and $72^{\circ} \mathrm{C}$ for $1.5 \mathrm{~min}$, and a final extension at $72^{\circ} \mathrm{C}$ for $10 \mathrm{~min}$. All PCR procedures were performed three times independently to compensate for technical failures. After mixing PCR products, fluorescence intensities of each sample were analysed using MultiNA (Shimadzu). PCRs were considered successful for samples with clear peaks.

\section{RESULTS}

PCR success rates for each method are indicated in Table 1. DNA fragments of 313,710 and 1555 bp were amplified for all the methods and leg samples immediately after preparing specimens. DNA fragments of $313 \mathrm{bp}$ were also amplified from all leg and body samples that were prepared using all the test methods and were stored for 0-12 months. Amplification rates of 710- and 1555-bp fragments, however, decreased with increase in the time the samples of legs were stored dry [Methods (1), (2), (3) and (4)] with decrease more for the 1555-bp than the 710-bp fragments. In contrast, the DNA fragments of 313-, 710- and 1555-bp were amplified successfully from samples of legs that were prepared using either $99.5 \%$ ethanol or $99 \%$ propylene glycol [Methods (5), (6), (7), (8) and (9)] after 0-12 months of storage. Differences in exposure times to ethyl acetate vapour or freezing did not affect amplification rates.

Table 1. Killing and preserving methods and PCR success rates using insect killed and preserved by each of the different methods.

\begin{tabular}{|c|c|c|c|c|c|c|c|}
\hline \multirow{2}{*}{ Method } & \multirow{2}{*}{$\begin{array}{l}\text { Method of killing } \\
\text { the insects }\end{array}$} & \multirow{2}{*}{ Preservation methods } & \multirow{2}{*}{$\begin{array}{l}\text { PCR Product } \\
\text { size (bp) }\end{array}$} & \multicolumn{4}{|c|}{${ }^{*}$ Success rate of PCR (\%) } \\
\hline & & & & ${ }^{* *}$ Immediate & 1 month & 6 month & 12 month \\
\hline \multirow{3}{*}{1} & \multirow{3}{*}{$\begin{array}{l}\text { Exposure to ethyl } \\
\text { acetate vapour (10 } \mathrm{min})\end{array}$} & \multirow{12}{*}{ Dried } & 313 & 100 & 100 & 100 & 100 \\
\hline & & & 710 & 100 & 100 & 87.5 & 100 \\
\hline & & & 1555 & 100 & 100 & 12.5 & 0 \\
\hline \multirow{3}{*}{2} & \multirow{3}{*}{$\begin{array}{l}\text { Exposure to ethyl } \\
\text { acetate vapour }(1 \mathrm{~h})\end{array}$} & & 313 & 100 & 100 & 100 & 100 \\
\hline & & & 710 & 100 & 100 & 25 & 50 \\
\hline & & & 1555 & 100 & 50 & 0 & 0 \\
\hline \multirow{3}{*}{3} & \multirow{3}{*}{$\begin{array}{l}\text { Exposure to ethyl } \\
\text { acetate vapour }(6 \mathrm{~h})\end{array}$} & & 313 & 100 & 100 & 100 & 100 \\
\hline & & & 710 & 100 & 100 & 50 & 62.5 \\
\hline & & & 1555 & 100 & 25 & 0 & 25 \\
\hline \multirow{3}{*}{4} & \multirow{3}{*}{ Frozen (24 h) } & & 313 & 100 & 100 & 100 & 100 \\
\hline & & & 710 & 100 & 87.5 & 50 & 62.5 \\
\hline & & & 1555 & 100 & 37.5 & 0 & 0 \\
\hline \multirow{3}{*}{5} & \multirow{6}{*}{$\begin{array}{l}\text { Exposure to ethyl } \\
\text { acetate vapour }(1 \mathrm{~h})\end{array}$} & \multirow{3}{*}{$\begin{array}{l}\text { Dehydrated in } 99.5 \% \text { ethanol }(24 \mathrm{~h}) \\
\text { and immersed in } 99.5 \% \text { ethanol }\end{array}$} & 313 & - & 100 & 100 & 100 \\
\hline & & & 710 & - & 100 & 100 & 100 \\
\hline & & & 1555 & - & 100 & 100 & 100 \\
\hline \multirow{3}{*}{6} & & \multirow{3}{*}{$\begin{array}{l}\text { Dehydrated in } 99.5 \% \text { ethanol }(24 \mathrm{~h}) \\
\text { and immersed in } 99 \% \text { propylene glycol }\end{array}$} & 313 & - & 100 & 100 & 100 \\
\hline & & & 710 & - & 100 & 100 & 100 \\
\hline & & & 1555 & - & 100 & 100 & 100 \\
\hline \multirow{3}{*}{7} & \multirow{6}{*}{ Frozen (24 h) } & \multirow{3}{*}{$\begin{array}{l}\text { Dehydrated in } 99.5 \% \text { ethanol }(24 \mathrm{~h}) \\
\text { and Immersed in } 99.5 \% \text { ethanol }\end{array}$} & 313 & - & 100 & 100 & 100 \\
\hline & & & 710 & - & 100 & 100 & 100 \\
\hline & & & 1555 & - & 100 & 100 & 100 \\
\hline \multirow{3}{*}{8} & & \multirow{3}{*}{$\begin{array}{l}\text { Dehydrated in } 99.5 \% \text { ethanol }(24 \mathrm{~h}) \\
\text { and immersed in } 99 \% \text { propylene glycol }\end{array}$} & 313 & - & 100 & 100 & 100 \\
\hline & & & 710 & - & 100 & 100 & 100 \\
\hline & & & 1555 & - & 100 & 100 & 100 \\
\hline \multirow{3}{*}{9} & \multirow{3}{*}{ Frozen $(24 \mathrm{~h})$} & \multirow{3}{*}{ Immersed in $99 \%$ propylene glycol } & 313 & - & 100 & 100 & 100 \\
\hline & & & 710 & - & 100 & 100 & 100 \\
\hline & & & 1555 & - & 100 & 100 & 100 \\
\hline
\end{tabular}

*Bold characters indicate PCR success lower than $100 \% .{ }^{* *}$ When analyses were performed immediately, DNA lengths were determined using only four methods [(1), (2), (3) and (4)] because the insects were killed in the same way in methods of (5), (6), (2), (4), (7), (8) and (9). 


\section{DISCUSSION}

Contrary to a previous study (Quicke et al., 1999), we observed no significant differences in the fragmentation of DNA of the insects killed either by exposure to ethyl acetate vapour or freezing. In this study, exposure to ethyl acetate vapour was too short (from $10 \mathrm{~min}$ to $6 \mathrm{~h}$ ) to cause significant fragmentation of the $1555 \mathrm{bp}$ during insect death. However, when killed by ethyl acetate vapour and dried slowly mounted on a pin DNA degrades rapidly (Quicke et al., 1999). Thus, to preserve long DNA fragments, killing times in ethyl acetate vapour should be short and tissues should be preserved in a freezer or in ethanol or propylene glycol as soon as possible.

Unlike the different modes of killing, those for preserving the tissues (immersion in ethanol or propylene glycol or drying) had significant effects on the fragmentation of the DNA in insect specimens. Many previous studies show that immersion of specimens in preservatives, such as, ethanol and propylene glycol preserve long fragments of DNA, whereas DNA in dried specimens rapidly degrades (Quicke et al., 1999; Vink et al., 2005; Hebert et al., 2013). Although dry specimens of insects, which contain only degraded DNA, have been widely used in genetic analyses, these analyses are much more difficult than when using fresh samples (Wandeler et al., 2007; Hebert et al., 2013; Nakahama et al., 2018). Although immersion in ethanol or propylene glycol may be appropriate for preserving long fragments of DNA, dried insects are more appropriate for morphological observations. Thus, we suggest that genetic information can be preserved in the legs kept in preservatives, leaving the bodies for morphological studies.

Fragmentation of DNA after immersion in propylene glycol did not differ between samples that were dehydrated and those that were not dehydrated. Generally, dehydration by substitution is recommended, because dilution by water from insect tissues can increase the risk of fragmenting DNA (Quicke et al., 1999; Stevens et al., 2011; Ferro et al., 2013). In this study, no serious fragmentation of DNA was recorded because only small amounts of tissue were preserved in the tubes. However, when large amounts of tissue are preserved, dehydration with $99.5 \%$ ethanol or propylene glycol may prevent dilution.

We could not determine whether fragments of DNA longer than $1556 \mathrm{bp}$ remain intact because we only tested PCR for 313-1555-bp fragments. Therefore, we do not conclude that this method of preserving DNA can be used in analyses that require very high-quality DNA, such as long PCR or restriction associated DNA sequence (RADseq) analyses (Miller et al., 2007). However, this method could be used at least for PCR-based analysis, such as sanger sequencing and microsatellite analysis. This method could also be used in high-throughput genotyping or sequencing techniques, which do not require high-quality DNA, such as genotyping using sequencing multiplexed ISSR (MIG-seq; Suyama \& Matsuki, 2015), target capture (Kawahara et al., 2018) and mitogenome resequencing (Mikheyev et al., 2017). Although this study did not determine the preservation of arthropod samples in $95 \%$ ethanol or acetone in a freezer (at $-20^{\circ} \mathrm{C}$ to $-80^{\circ} \mathrm{C}$ ), this method is recommended for analyses requiring very high-quality DNA (Quicke et al., 1999; Vink et al., 2005). Although this is the best method for preserving the quality of DNA when there is sufficient space, our method has the advantage of maintaining a certain DNA length $(\sim 1555 \mathrm{bp})$ at a lower cost in terms of maintenance and space. We also assessed samples that were stored for up to 12 months. In future studies, we will report the rates of fragmentation of DNA in samples preserved for 10 years.

In this study, we could not determine how many times DNA can be extracted from preserved samples of legs, because the amount of DNA remaining in samples of legs was not assessed. If we attempted to reuse a leg from which DNA had already been extracted, extracting a large amount of DNA would not have been possible because the muscle tissue had already been digested by proteinase $\mathrm{K}$. For PCR-based analyses that do not require a large amount of DNA, it may be appropriate to use part of the leg tissue and preserve the remaining tissue for future analysis.

Fragments of DNA of 1555 bp were amplified from samples of legs that were preserved in either $99.5 \%$ ethanol or $99 \%$ propylene glycol, whose evaporation rates (compared with n-butyl acetate $=1$ ) are 1.4 and 0.01 , respectively. Whereas propylene glycol is less likely to evaporate than ethanol, exposure to UV can result in the decomposition of propylene glycol into other substances, such as water, acetone and 2-propanol (Inoue et al., 1966; Kim \& Hoffman, 2008). Thus, if the specimens are exposed to light, tubes containing samples of DNA in propylene glycol should be wrapped in aluminium foil to protect the contents from light. In addition, if the $0.2 \mathrm{ml}$ tube can rotate there is a risk that it will damage surrounding specimens, therefore, the samples of DNA in tubes should be prevented from rotating by means of insect pins.

The methods for preserving samples of DNA along with dry insect specimens we recommend are depicted in Fig. 1 as follows: (I) insects should be killed by exposing them to ethyl acetate vapour for a short period of time $(\sim 1 \mathrm{~h})$ or by freezing; (II) legs (or other tissues) should be removed immediately from the body and preserved in $0.2 \mathrm{ml} \mathrm{PCR}$ tubes containing $99 \%$ propylene glycol. If the volume of the legs is too large for the tubes, the legs should be dehydrated using either $99 \%$ ethanol or propylene glycol; (III) insert the insect pin on which the sample is impaled into the hinge of a $0.2 \mathrm{ml}$ tube and keep this DNA sample with the dried specimen. If the specimen is to be exposed to light, wrap the tube in aluminium foil to prevent degradation of propylene glycol; (IV) then fix the $0.2 \mathrm{ml}$ tube with insect pins to prevent it rotating and damaging surrounding specimens. This method does not require expensive items or reagents. Collecting of specimens along with preserved DNA will make historical genetic information available.

In this study, we developed a method for preserving the DNA with dried specimens of insects. After preservation in $99 \%$ propylene glycol long fragments of DNA (at least $1555 \mathrm{bp}$ ) remain intact for at least a year. This method can be used when space is limited and has the added advanta- 
ges that it costs very little and preserves morphological information, because the DNA samples are preserved along with the dried specimens. Therefore, this method will add value by making dried specimens of insects a genetic resource.

ACKNOWLEDGEMENTS. We are grateful to S. Yonezawa and G. Kinoshita for helping with the molecular analyses. This work was supported by a Grant-in-Aid for Scientific Research (17J00965 and 19K15856) from the Japan Society for the Promotion of Science.

\section{REFERENCES}

Baba K. \& Hirashima Y. 2000: Science of Insect Collecting. New $E d$. Kyushu University Press, Fukuoka, 810 pp. [in Japanese].

FERRO M.L. \& PARK J.S. 2013: Effect of propylene glycol concentration on mid-term DNA preservation of Coleoptera. Coleopt. Bull. 67: 581-587.

Folmer O., Black M., Hoen W., Lutz R. \& Vrijenhoek R. 1994: DNA primers for amplification of mitochondrial cytochrome $\mathrm{c}$ oxidase subunit I from diverse metazoan invertebrates. - Mol. Mar. Biol. Biotechnol. 3: 294-299.

Haran J., Delvare G., Vayssieres J.F., Benoit L., Cruaud P., RASPLUS J.Y. \& CRUAUD A. 2018: Increasing the utility of barcode databases through high-throughput sequencing of amplicons from dried museum specimens, an example on parasitic Hymenoptera (Braconidae). - Biol. Contr. 122: 93-100.

Hausmann A., Miller S.E., Holloway J.D., Dewaard J.R., Pollock D., Prosser S.W. \& Hebert P.D. 2016: Calibrating the taxonomy of a megadiverse insect family: 3000 DNA barcodes from geometrid type specimens (Lepidoptera, Geometridae). - Genome 59: 671-684.

Hebert P.D., deWaard J.R., Zakharov E.V., Prosser S.W., Sones J.E., McKeown J.T., Mantle B. \& La Salle J. 2013: A DNA 'Barcode Blitz': Rapid digitization and sequencing of a natural history collection. - PLOS ONE 8(7): e68535, 14 pp.

Inoue H., TAmaki K. \& Iмото E. 1966: Photo-oxidation of glycols in the liquid phase. - J. Chem. Soc. Jap. 69: 654-657 [in Japanese].

Kawahara A.Y., Breinholt J.W., Espeland M., Storer C., PlotKIN D., DeXter K.M., Toussaint E.F.A., St Laurent R.A., Brehm G. \& Vargas S. 2018: Phylogenetics of moth-like butterflies (Papilionoidea: Hedylidae) based on a new 13-locus target capture probe set. - Mol. Phylogenet. Evol. 127: 600-605.

Kigawa R., Nochide H., Kimura H. \& Miura S. 2003: Effects of various fumigants, thermal methods and carbon dioxide treatment on DNA extraction and amplification: A case study on freeze-dried mushroom and freeze-dried muscle specimens. Collect. Forum 18: 74-89.

Kim K.N. \& Hoffmann M.R. 2008: Heterogeneous photocatalytic degradation of ethylene glycol and propylene glycol. - Kor. J. Chem. Eng. 25: 89-94.

Leray M., Yang J.Y., Meyer C.P., Mills S.C., Agudelo N., Ranwez V., Bоенм J.T. \& Machida R.J. 2013: A new versatile primer set targeting a short fragment of the mitochondrial COI region for metabarcoding metazoan diversity: application for characterizing coral reef fish gut contents. - Front. Zool. 10: 34, $14 \mathrm{pp}$.

Mikheyev A.S., Zwick A., Magrath M.J., Grau M.L., Qiu L., Su Y.N. \& YeATES D. 2017: Museum genomics confirms that the Lord Howe Island stick insect survived extinction. - Curr. Biol. 27: 3157-3161.
Miller M.R., Dunham J.P., Amores A., Cresko W.A. \& Johnson E.A. 2007: Rapid and cost-effective polymorphism identification and genotyping using restriction site associated DNA (RAD) markers. - Genome Res. 17: 240-248.

Naem S., Pagan C. \& Nadler S.A. 2010: Structural restoration of nematodes and acanthocephalans fixed in high percentage alcohol using DESS solution and rehydration. - J. Parasitol. 96: 809-812.

NAKAHAMA N. \& ISAGI Y. 2017: Availability of short microsatellite markers from butterfly museums and private specimens. - Entomol. Sci. 20: 3-6.

Nakahama N., Uchida K., Ushimaru A. \& Isagi Y. 2018: Historical changes in grassland area determined the demography of semi-natural grassland butterflies in Japan. - Heredity 121: $155-168$.

Nasu Y., Hirowatari T. \& Yoshiyasu Y. 2016: Introdution to Lepidopterology - Technics for Breeding, Dissection and DNA Analysis. Tokai University Press, Kanagawa, 295 pp. [in Japanese].

Quicke D.L., Lopez-Vaamonde C. \& Belshaw R. 1999: Preservation of hymenopteran specimens for subsequent molecular and morphological study. - Zool. Scr. 28: 261-267.

Reiss R.A., SCHWERT D.P. \& Ashworth A.C. 1995: Field preservation of Coleoptera for molecular genetic analyses. - Environ. Entomol. 24: 716-719.

Rohland N., Siedel H. \& Hofreiter M. 2004: Nondestructive DNA extraction method for mitochondrial DNA analyses of museum specimens. - Biotechniques 36: 814-821.

SÄrkinen T., StaAts M., Richardson J.E., Cowan R.S. \& BakkeR F.T. 2012: How to open the treasure chest? Optimising DNA extraction from herbarium specimens. - PLOS ONE 7(8): e43808, 9 pp.

Simon C., Frati F., Beckenbach A., Crespi B., Liu H. \& Flook P. 1994: Evolution, weighting, and phylogenetic utility of mitochondrial gene sequences and a compilation of conserved polymerase chain reaction primers. - Ann. Entomol. Soc. Am. 87: 651-701.

Stevens M.M., Warren G.N., Mo J. \& Schlipalius D.I. 2011: Maintaining DNA quality in stored-grain beetles caught in Lindgren funnel traps. - J. Stored Prod. Res. 47: 69-75.

Suchan T., Pitteloud C., Gerasimova N.S., Kostikova A., Schmid S., Arrigo N., Pajkovic M., Ronikier M. \& Alvarez N. 2016: Hybridization capture using RAD probes (hyRAD), a new tool for performing genomic analyses on collection specimens. PLOS ONE 11(3): e0151651, 22 pp.

SuYAMA Y. \& MatsuKi Y. 2015: MIG-seq: an effective PCR-based method for genome-wide single-nucleotide polymorphism genotyping using the next-generation sequencing platform. Sci. Rep. 5: 16963,12 pp.

Tin M.M.Y., Economo E.P. \& Mikheyev A.S. 2014: Sequencing degraded DNA from non-destructively sampled museum specimens for RAD-tagging and low-coverage shotgun phylogenetics. - PLoS ONE 9(5): e96793, 9 pp.

Vink C.J., Thomas S.M., Paquin P., Hayashi C.Y. \& Hedin M. 2005: The effects of preservatives and temperatures on arachnid DNA. - Invertebr. Syst. 19: 99-104.

WANDEler P., Hoeck P.E. \& Keller L.F. 2007: Back to the future: museum specimens in population genetics. - Trends Ecol. Evol. 22: 634-642.

Received September 5, 2019; revised and accepted December 4, 2019 Published online December 23, 2019 


\section{Appendix 1. The DNA extraction protocol}

\section{Solutions and reagents}

- CTAB buffer: 1\% CTAB (Cetyl trimethyl ammonium bromide), $0.7 \mathrm{M} \mathrm{NaCl}, 13 \mathrm{mM}$ EDTA-2Na, $50 \mathrm{mM}$ Tris- $\mathrm{HCl}$ ( $\mathrm{pH}$ $8.0)$

- $100 \%$ isopropanol

- 1M DTT (DL-Dithiothreitol)

- $3 \%$ SDS

- $70 \%$ ethanol

- Proteinase K 20mg/ml

- RNase A

- TE (Tris-EDTA) buffer

- TE saturated phenol

- Chloroform: isoamyl alcohol $(24: 1)$

\section{DNA extraction}

- Transfer one front or middle leg to a $1.5 \mathrm{ml}$ tube.

- Add $235 \mu 1$ of CTAB buffer, $15 \mu 1$ of 3\% SDS, $5 \mu 1$ of Proteinase $\mathrm{K}$, and $13.4 \mu \mathrm{l}$ of DTT.

- Spin down and incubate at $56^{\circ} \mathrm{C}$ overnight.

- Add $125 \mu 1$ of TE saturated phenol, $125 \mu 1$ of chloroform isoamyl alcohol $(24: 1)$. Mix well.

- Centrifuge at 6,000 rpm for $10 \mathrm{~min}$ at room temperature.

- Transfer $200 \mu$ l of supernatant to a new tube.

- Add $200 \mu 1$ of $100 \%$ isopropanol. Mix well.

- Centrifuge at 6,000 rpm for $8 \mathrm{~min}$ at room temperature.

- Discard the supernatant

- Add $200 \mu 1$ of $70 \%$ ethanol.

- Centrifuge at 6,000 rpm for 8 min at room temperature.

- Discard the supernatant. Air dry pellet.

- Resuspend pellet in $30 \mu 1$ of TE buffer. 